\title{
Імплементація сдиних розвідувальних процедур на оперативно-тактичному рівні - шлях до переваги на полі бою
}

Резюме. У статті описано принципи, що містяться в деяких оновлених доктринах НАТО. Показана можливість підвищення ефективності управління розвідкою (в умовах великої кількості засобів розвідки, задіяних в операції) шляхом впровадження JISR-процесу для сприяння прийняттю військових рішень, що дасть змогу не тільки вчасно реагувати, а й запобігти діям противника.

Ключові слова: цикл розвідки; об’єднання; управління збором; вимоги до розвідки; взаємодія; синхронізація; наіменована зона інтересу; ціле виявлення; делегування повноважень; правила бойового застосування.

Постановка проблеми. "Інформація та розвідка для XXI століття $є$ тим же, чим для $\mathrm{XX}$ були вогневе ураження i маневр" адмірал Джеймс Ставрідіс, Головнокомандувач об'єднаними збройними силами НАТО в Європі 2009 - 2013 рр. [1]. Це твердження не применшує значущості маневру і вогневого ураження, а підкреслює високий темп розвитку інформаційних технологій у XXI столітті на порядок більший, ніж будь-яких інших. Під час ефективного їх використання наявні на полі бою засоби розвідки й ураження концентруються у потрібний час, у потрібному місці, в необхідній кількості, що дає змогу досягти переваги над противником $\mathrm{i}$, навпаки, недовикористання інформаційних технологій унеможливлює максимізацію сил операцій і сприяє втраті ініціативи і шансу на успіх.

Аналіз останніх досліджень i публікацій. У статті розглянуто принципи деяких оновлених доктрин розвідки НАТО, опублікованих у 2016 р., які займають в архітектурі спільних доктрин порядок, наведений на рис. 1 [2-9]. Ці доктрини призначені, передусім, для особового складу підрозділів оперативного рівня, але застосовуються персоналом усіх рівнів. Доктрини описують фундаментальні принципи, практики і процедури, якими керуються збройні сили для досягнення цілей Об' єднаних операцій $[5]$.

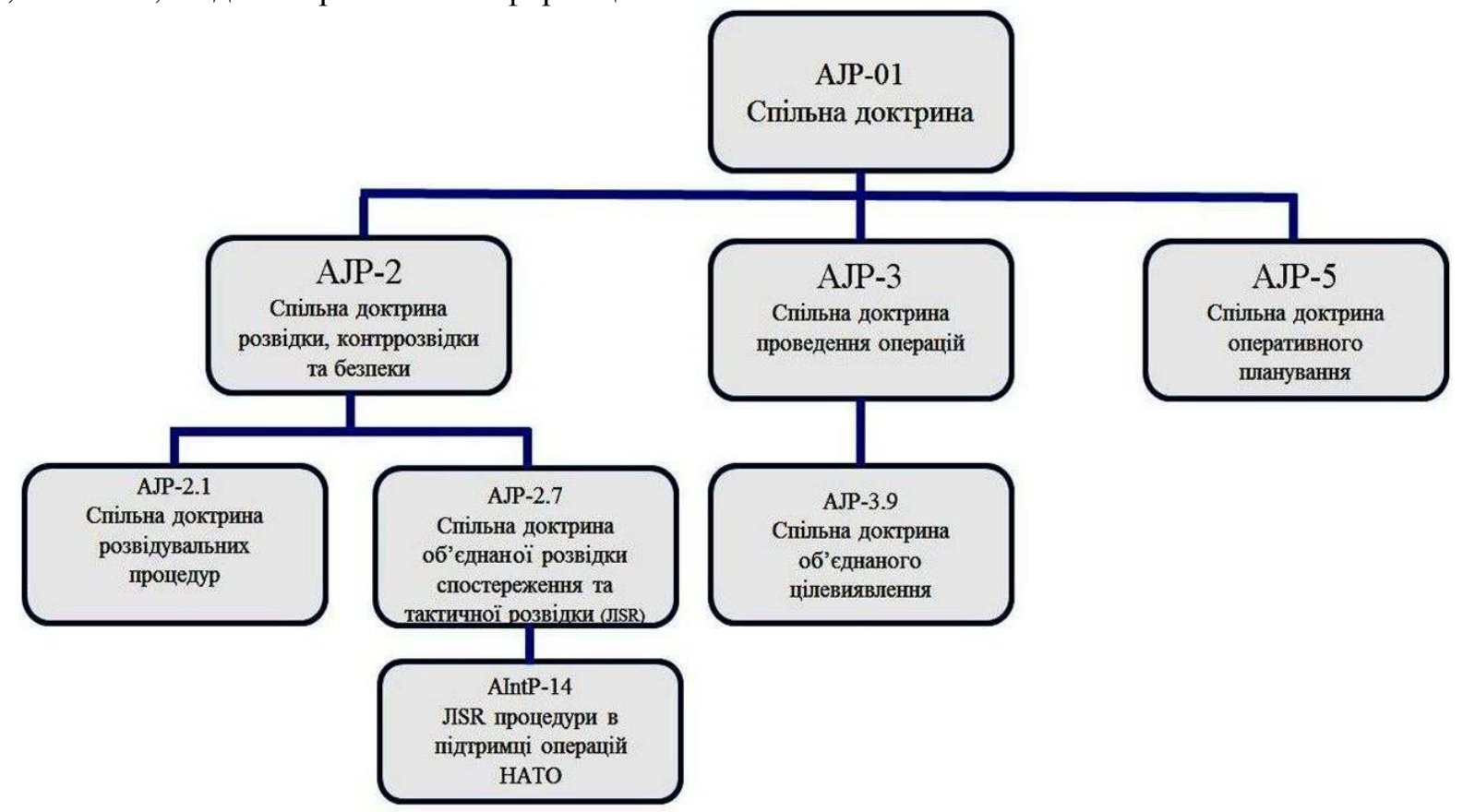

Рис. 1. Порядок доктрин розвідки й операцій в архітектурі спільних доктрин НАТО

Метою статті $\epsilon$ розгляд оновлених процедур НАТО в контексті можливості їх застосування підрозділами
Об'єднаних сил (ООС) i наголошення необхідності оперування єдиними процедурами персоналом підрозділів ООС, який має справу 3 
багатьма джерелами розвідданих, оскільки ефективність застосування інформаційних технологій залежить, у першу чергу, від професійності персоналу. "Люди центральний компонент функцій військової розвідки і ми продовжуємо ставити акцент на людських аспектах нашої професії” [10] генерал Грег С. Поттер, директор розвідки НАТО в Афганістані.

Виклад основного матеріалу. Упродовж чотирьох років відбиття збройної агресії українські війська в рази збільшили використання технічних засобів розвідки, в тому числі радарів контрбатарейної боротьби та безпілотних літальних апаратів (БПЛА). Для максимального використання можливостей засобів розвідки та стандартизованого виконання функцій розвідки - постачання ситуаційного розуміння і сприяння прийняттю доцільного військового рішення - усі підрозділи мають діяти на основі єдиних принципів. Основним принципом розвідувальних процедур $\epsilon$ використання розвідувального циклу послідовності дій, за допомогою яких інформація отримується, зводиться, перетворюється на розвідувальну інформацію i стає доступною для користувачів. Ці дії характеризуються цілеспрямованістю чотирьох базових етапів розвідки: управління, збір, обробка і поширення (рис. 2.) [3].

Незважаючи на цикл розвідки, який зовні виглядає як простий процес, насправді це комплекс заходів, що складається 3 багатьох циклів, які діють на різних рівнях і швидкостях. Кілька циклів можуть відбуватися одночасно. Деякі завдання циклу перекривають одне одного, збігаються і часто проводяться одночасно, а не послідовно [4].

Утім оновлення принципів у доктринах стосується управління вимогами до розвідки (IRM - intelligence requirements management) та управління збором (CM - collection management), які регулюють функції комплексного управління особовим складом при виконанні розвідувального циклу. Управління вимогами до розвідки та управління збором $\epsilon$ сукупністю процесів управління, спрямованих на оптимальне використання спроможностей збору. Відповідальним за проведення цих процедур $\epsilon$ особовий склад секцій розвідки штабів, без яких цикл розвідки стане перенавантаженим.

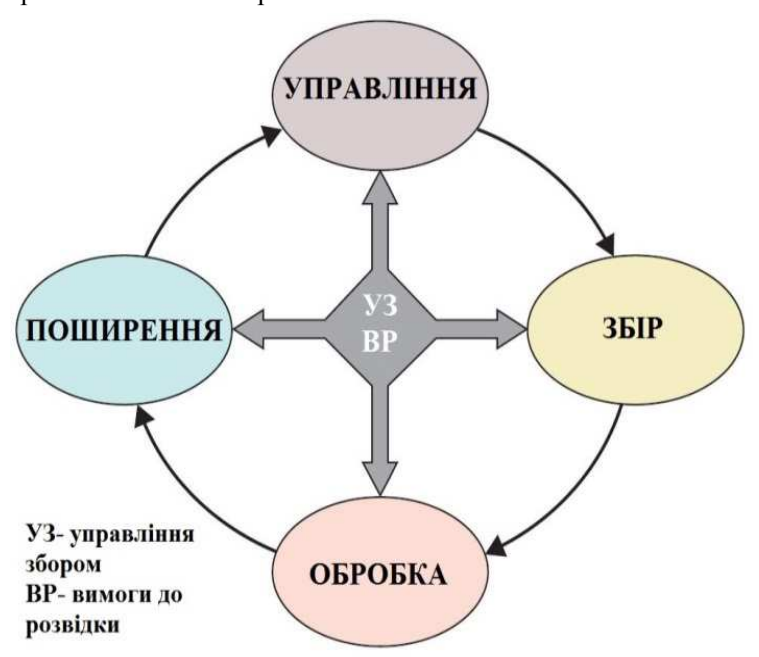

Рис. 2. Розвідувальний цикл

Управління вимогами до розвідки (ВР) це сукупність інтегрованих служб та процесів управління, які розробляють, затверджують, визначають пріоритети вимог до розвідки, ініціюють збір пов'язаної інформації; здійснюють контроль якості оброблених даних і нагляд за поширенням (доведенням) результатів розвідки.

Управління збором (УЗ) - це процес перетворення вимог до розвідки на вимоги щодо збору інформації, постановки задач та координації застосування конкретних інструментів збору, моніторингу та повторних постановок задач, що сприяе оптимальному застосуванню спроможностей збору. Персонал, на який покладене виконання цих процедур потребує безперервного й тісного зв'язку 3 різними джерелами збору, обробки й поширення для якнайшвидшого коригування, уникнення дублювання, забезпечення відповідності процесу збору вимогам до розвідки і виконання плану збору.

Іншою провідною темою оновлених розвідувальних доктрин є поліпшення взаємодії 3 операційними процесами, для чого ініційовано JISR-процес, який дає змргу персоналу розвідувальних та операційних секцій штабів координувати, синхронізувати, деконфліктувати багатоджерельні засоби збору 3 усіма пов'язаними спроможностями обробки i використовувати їх ефективно i своєчасно. JISR-процес сприяє досягненню зазначеними секціями штабів поставлених командиром цілей i забезпечує швидке прийняття обгрунтованого військового рішення.

JISR (Joint Intelligence, Surveillance and Reconnaissance) - “Об'єднані Розвідка, Спостереження й Тактична розвідка" - це набір розвідувальних та операційних спроможностей, поєднаних в єдину архітектуру для планування і досягнення вимог командира. Термін 
“об’єднані” (J) застосовується для дій, до яких залучені два і більше учасників, що оперують в єдиному середовищі.

JISR-процес виконується в п’ять послідовних кроків: вимоги (task), збір (collect), обробка (process), використання (exploit) і поширення (disseminate), які мають абревіатуру TCPED (рис. 3) [5].

\section{The JISR Process}

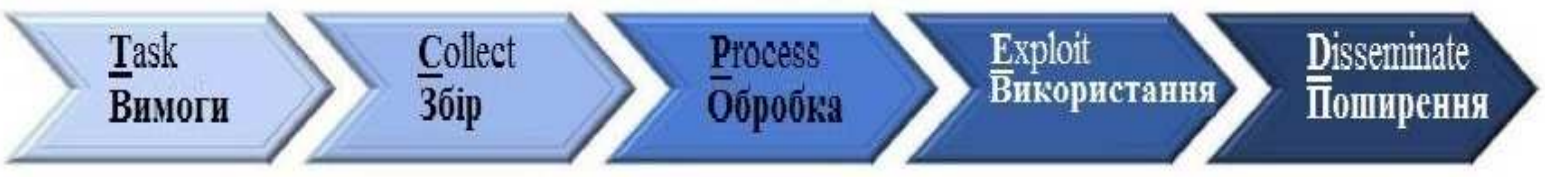

Рис. 3. JISR-процес (кроки TCPED)

Ha JISR-процес покладається місія забезпечити командира всіма специфічними даними, інформацією i ситуаційною обізнаністю, що стосується збору інформації в процесі проведення операції. Така архітектура процесу дає змогу інтегрувати наявні розвідувальні спроможності в загальну схему маневру операції.

Розвідка є лише частиною операції, а пріоритети операції в цілому, місце та діяльність розвідки в підтримці операції визначає командир. Надання "вимог" (tasking) є першим кроком JISR-процесу, який полягає в чітких вимогах до збору у вигляді інструкцій i наказів для координації та контролю JISR-засобів. На цьому кроці задіюються функції персоналу штабу 3 управління вимогами до розвідки (IRM) та визначають оптимальні джерела розвідки 3 огляду на операційну необхідність, ризики застосування, обмежену наявність інструментів. Малоймовірно, що особовий склад розвідки колись матиме достатню кількість людей або ресурсів, аби задовольнити всім запитам. Ведення розвідки має бути заздалегідь сплановано й організовано настільки надійно, наскільки це можливо в межах наявних обмежень. Для іiі успішного ведення мають бути визначені пріоритети процесу розвідки, враховуючи, що вимоги не завжди відповідають наявним спроможностям.

Другий крок JISR-процесу - “збір” (collect) - полягає в безпосередньому зборі даних в операційному просторі. JISR-засоби збирають дані, визначені вимогами, i передають їх для подальшої обробки.

Третій крок - “обробка” (process) полягає в конвертації зібраних даних у встановлені, зручні формати, які дозволяють візуалізацію, подальше використання, зберігання i поширення оброблених даних. Головною вимогою виконання цього кроку $є$ побудова єдиної інформаційної мережі, завдяки якій добиваються ефекту синергії, коли ефективність від сумісної дії об'єднаних у мережу сил за сукупним результатом перевищує сумарну ефективність від застосування тих же сил та засобів окремо [11]. Поширення оброблених даних в єдиній мережі $\epsilon$ важливим для обробки даних $з$ інших джерел розвідки, які в цей же час задіяні в цій або суміжній зоні відповідальності. Горизонтальні 3в'язки сприяють поширенню розуміння, що $\epsilon$ істотним для оптимізації застосування різних джерел розвідки. Кожне джерело у співпраці 3 іншими може відкоригувати власний збір даних i поліпшити якість інформації в результаті їх обробки.

Четвертий крок JISR-процесу “використання" (exploit). На цьому кроці приймається рішення як саме використати зібрану й оброблену інформацію, яка оцінюється на предмет відповідності вимогам до розвідки i, залежно від відповідності, або негайно поширюється авторизованим запитувачам, або спрямовується на дорозвідку iз застосуванням функції управління збором (CM). На цьому кроці персонал приймає складні рішення, які є результатом оцінювання інформації та обстановки, що склалася за критеріями: "кількість-якість", “обгрунтованість-нагальність", “поширеннясекретність” тощо. Залежно від ситуації негайне поширення інформації, яка на 80 \% відповідає вимогам, може бути пріоритетним порівняно 3 поширенням обгрунтованої на $100 \%$, але 3 втратою часу, і навпаки.

П'ятий крок JISR-процесу "поширення" (dissemination) включає своєчасне постачання JISR-результатів авторизованим запитувачам в необхідному форматі обумовленими каналами комунікації. Важливо, щоб поширювана ситуаційна обізнаність була стислою i наочною для уникнення переобтяження командира.

Кроки TCPED $\epsilon$ необхідними для отримання ситуаційної обізнаності та сприяння 
прийняттю військового рішення. Нехтування хоча б одним кроком веде до втрати важливих даних із бойового простору - слабкість однієї ланки послаблює весь ланцюг.

\section{Практичні нюанси застосування} кроків TCPED на оперативно-тактичному piвні. На тепер в ООС представлені засоби різних підрозділів розвідки: сигнальної (в т.ч. комунікаційної та електронної), радіолокаційної, звукової, оптичної, електронно-оптичної, агентурної тощо. Вони мають різні ступені точності, потужності, досяжності, але ефективність кожного 3 них може бути збільшена до власного максимуму за рахунок застосування в надійній об'єднаній архітектурі за єдиними процедурами, яких дотримуватимуться всі підрозділи.

В операціях НАТО процедури TCPED застосовуються на будь-якому рівні операції від окремої одиниці, тактичного підрозділу, Об'єднаних сил до багатонаціональних операцій [6].

У зоні відбиття збройної агресії територія операційного простору в переважній більшості представлена типовим ландшафтом, приклад якого наведено на рис. 4.

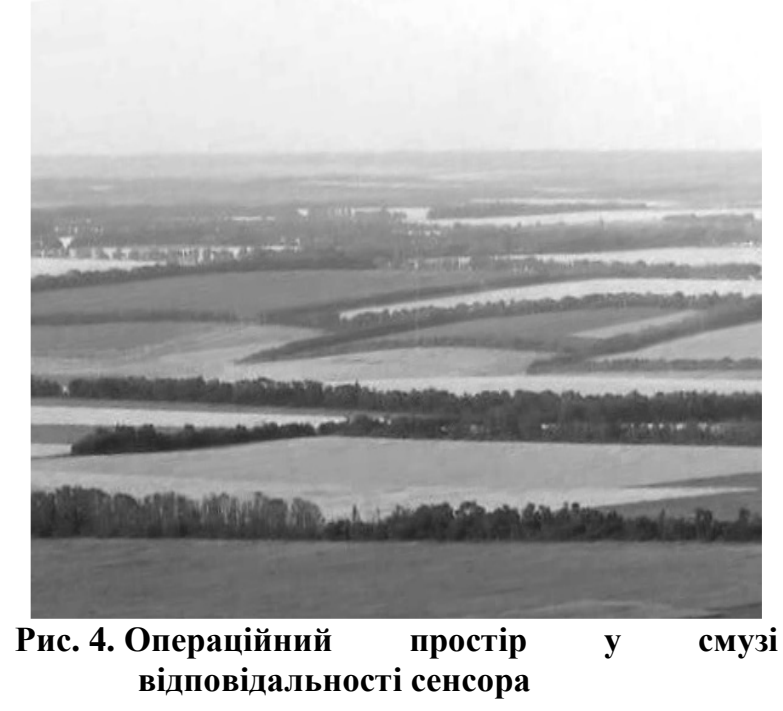

Фіксація дій противника зі спостережних постів часто ускладнене ландшафтом, а зони відповідальності мають значні розміри. Управління вимогами до розвідки вирішує питання "як використати наявні засоби розвідки”. Для економії ресурсів в умовах обмежених розвідувальних спроможностей використовуються не тільки власні сили, але й інформація, поширена засобами приданих i суміжних підрозділів.

Приклад даних, зібраних одним джерелом розвідки в операційному просторі за певний проміжок часу, наведено на рис. 5.
Тут показано набір необроблених даних (відміток - крапкових знаків) про об'єкти розвідки, отриманих джерелом технічної розвідки і нанесених на зону відповідальності системи візуалізації бойового простору.

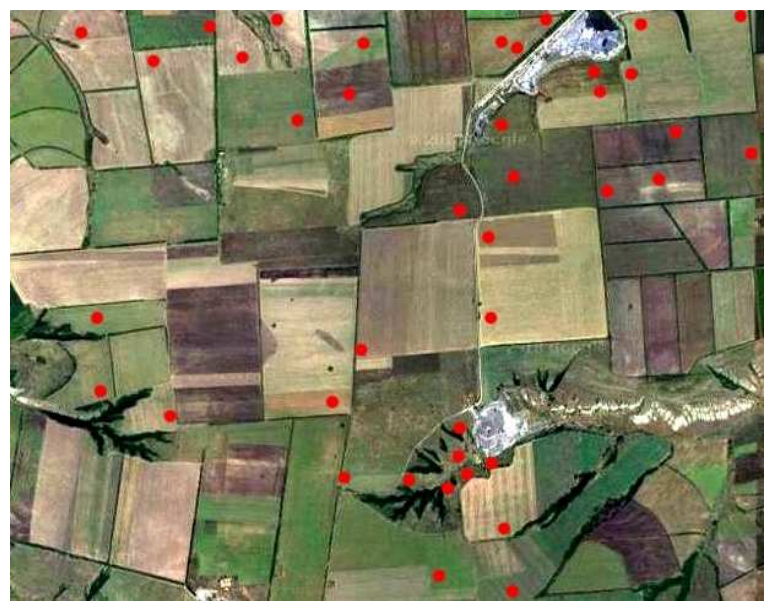

Рис. 5. Дані, зібрані у форматі масиву і нанесені в системі візуалізації бойового простору

Розвідувальна інформація в такому необробленому вигляді $є$ малоінформативною i непридатною для персоналу командного рівня. Потрапивши без обробки на рівень відповідного командира, вона буде втрачена враховуючи, що в його підпорядкуванні знаходиться кілька засобів розвідки. Масиви необроблених даних не пришвидшують процес прийняття військового рішення. Між тим у необробленому масиві є критично важливі дані, які після обробки можуть або визначити й локалізувати зміну стану бойового простору, або стати індикатором для спрямування дій інших джерел розвідки.

Часто такі дані, нанесені в систему візуалізації поля бою, засмічують загальну операційну картину (COP - common operational picture) i замість допомоги спричиняють зворотній процес. Саме тому обов'язком персоналу управління розвідки тактичного рівня $\epsilon$ обробка зібраних даних для відсортування адекватних даних, що відповідають вимогам розвідки. Обробка даних (хоч здебільшого й автоматизована) обовязково вимагає певних навиків і критичного мислення, тому має виконуватися командирами груп (відділень/взводів) на тактичному рівні або командирами певних модулів, якщо джерела різних видів розвідки об'єднані в систему STAR (surveillance, target acquisition, reconnaissance) [12]. Процес обробки даних включає співставлення, порівняння 3 даними 3 інших джерел, оцінювання джерел на надійність (від повністю надійних до повністю ненадійних). Співставленню підлягають усі дані сенсорів: від дирекційного кута на спалах від ворожої 
артилерійської системи і азимута воронки [13] до зміни позивних у порядках противника. Приклад оброблених даних різних інструментів розвідки 3 операційного простору, внесених до розвідувального шару загальної операційної картини, наведено на рис. 6. Тут показано набір оброблених даних (відміток - крапкових знаків) про обєкти розвідки, отриманих від різних джерел технічної розвідки.
Результатом обробки даних стає локалізація змін в оперативному просторі, що дає можливість досягти економії обмежених спроможностей після визначення наіменованих зон інтересу розвідки (NAI - named area of interest) - обмеженої території, де відбувається цілеспрямований збір специфічних даних. У цьому випадку, кожному об' єкту розвдіки зони NAI (рис. 6) присвоюється класифікована ознака, що містить дані про характер цього об'єкта.

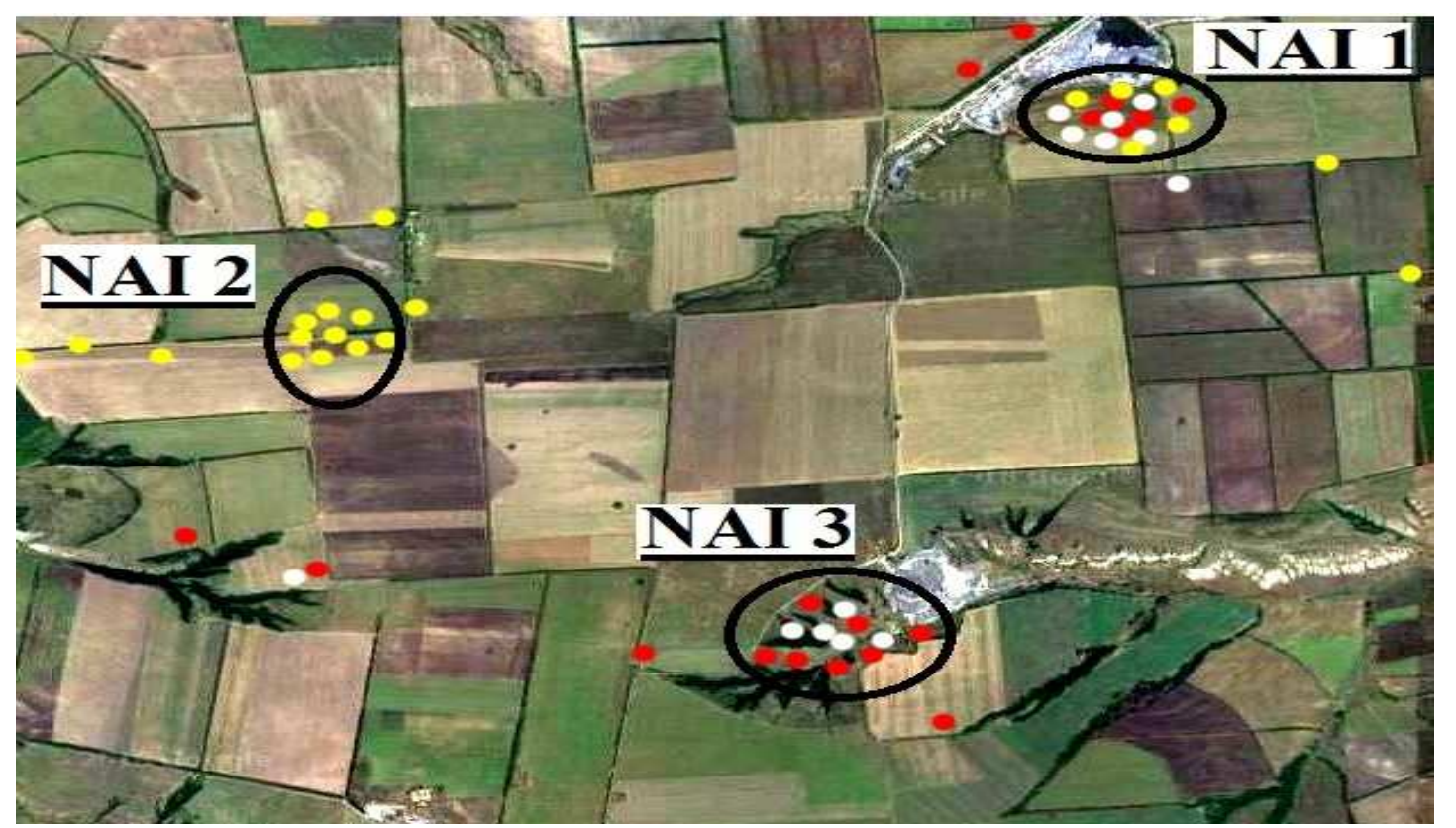

Рис. 6. Інформація - зібрані дані, оброблені методом співставлення 3 подальшою візуалізацісю

Рішення “як використати інформацію" приймається секцією розвідки S2/G2 на кроці “використання" за результатами проведення таких процедур:

аналіз;

інтерпретація.

У процесі аналізу оброблена інформація перевіряється на важливість у конкретній ситуаціі, можливість зробити прогноз майбутніх дій противника. Надалі вона підлягає інтерпретації, за якої оцінюється на правдоподібність 3 огляду на обстановку, військовий досвід, ситуаційну обізнаність (від високоймовірної до неймовірної).

Після аналізу та інтерпретації, персонал, відповідальний за процедури кроку “використання”, приймає рішення про негайне "поширення" отриманої ситуаційної обізнаності в мережі або проведення дорозвідки. При рішенні на користь дорозвідки формулюють специфічні, уточнені вимоги у вигляді першочергових вимог до розвідки (PIR - priority intelligence requirements) - вимог, у яких передбачається результат або ставляться пріоритети.
Без визначення пріоритетів можлива втрата ефективність високоточних інструментів розвідки таких, як контрбатарейні радари i БПЛА. Для запобігання цьому і використанню максимальної ефективності новітніх засобів розвідки у 2005 році було впроваджено "Архітектуру взаємодії розвідки, спостереження і тактичної розвідки НАТО" (NIIA - NATO Intelligence, Surveillance, and Reconnaissance Interoperability Architecture). Поява БПЛА у великих кількостях зумовила необхідність забезпечення їх коректного застосування в цій архітектурі, де вперше було узгоджено взаємодію в одних рамках електронно-оптичних, комунікаційних, сигнальних та інших засобів розвідки [14]. Спостереження не може здобути на $100 \%$ точних i достовірних даних, a тактична розвідка не може бути застосована ефективно без вхідних результатів цілодобового та повноцінного спостереження. У цьому випадку взаємодія визначається як спроможність систем, підрозділів або сил надавати чи приймати інформацію від інших систем, підрозділів або сил, щоб, скориставшись цією інформацією, ефективніше виконувати спільну 
місію. До того ж, наприклад, управління збором відбувається як при плануванні польоту БПЛА, так і під час польоту у разі отримання інформації від інших сенсорів про зміни в операційному середовищі.

Приклад неповного використання спроможностей БПЛА наведено на рис. 7.
Коли користувач засобу розвідки має в межах об'єктива операційний простір без визначених пріоритетних вимог та інформації 3 інших сенсорів, результати використання БПЛА майже завжди будуть незадовільні та неінформативні.

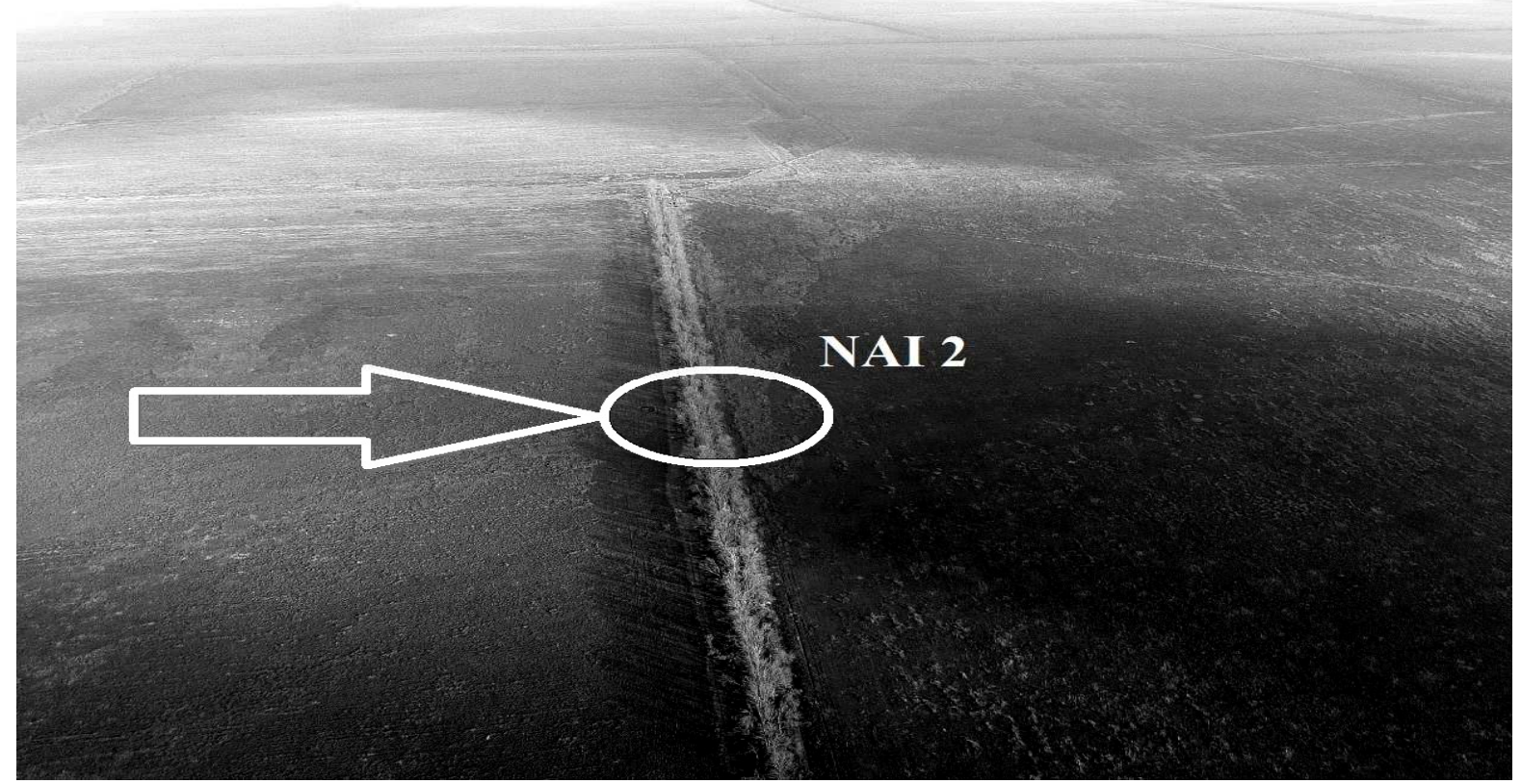

Рис. 7. Бойовий простір з визначеними першочерговими вимогами до розвідки (PIR)

Надавши чіткі специфічні вимоги для тактичної розвідки, зберігши можливість використовувати дані 3 інших сенсорів i застосувавши техніку перехресного спрямування (Cross-cueing) можна розраховувати на підтвердження передбачуваної ситуаційної обізнаності пов'язаних даних.

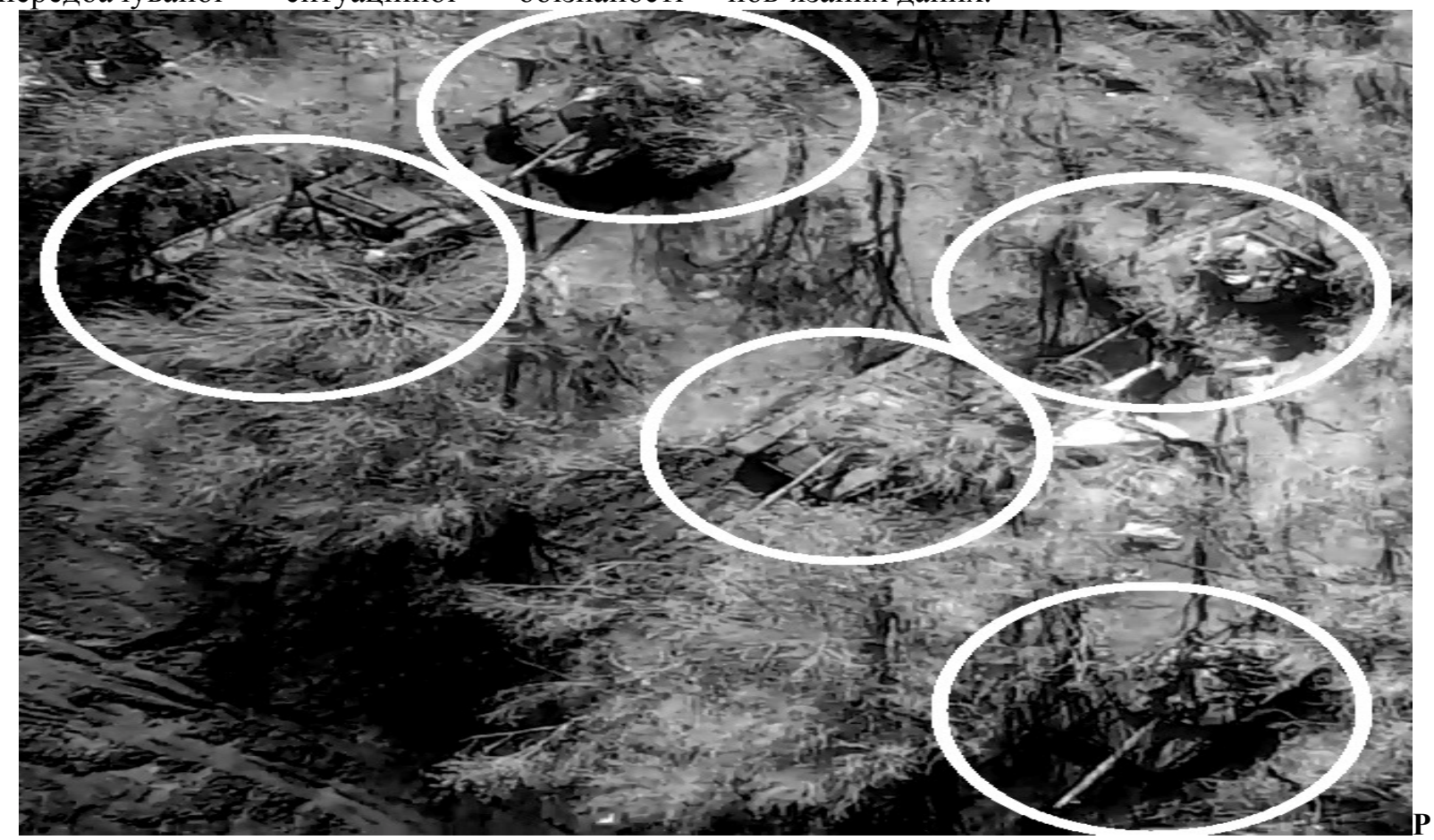

Рис. 8. Ситуаційна обізнаність у вигляді виявленої цілі 
Архітектура взаємодії розвідки, спостереження і тактичної розвідки дає змогу досягти найефективнішого результату через оптимальне застосування новітніх засобів розвідки у взаємодії 3 давно існуючими засобами. Приклад планування польоту БПЛА на кроці “використання" [14] наведено на рис. 9.

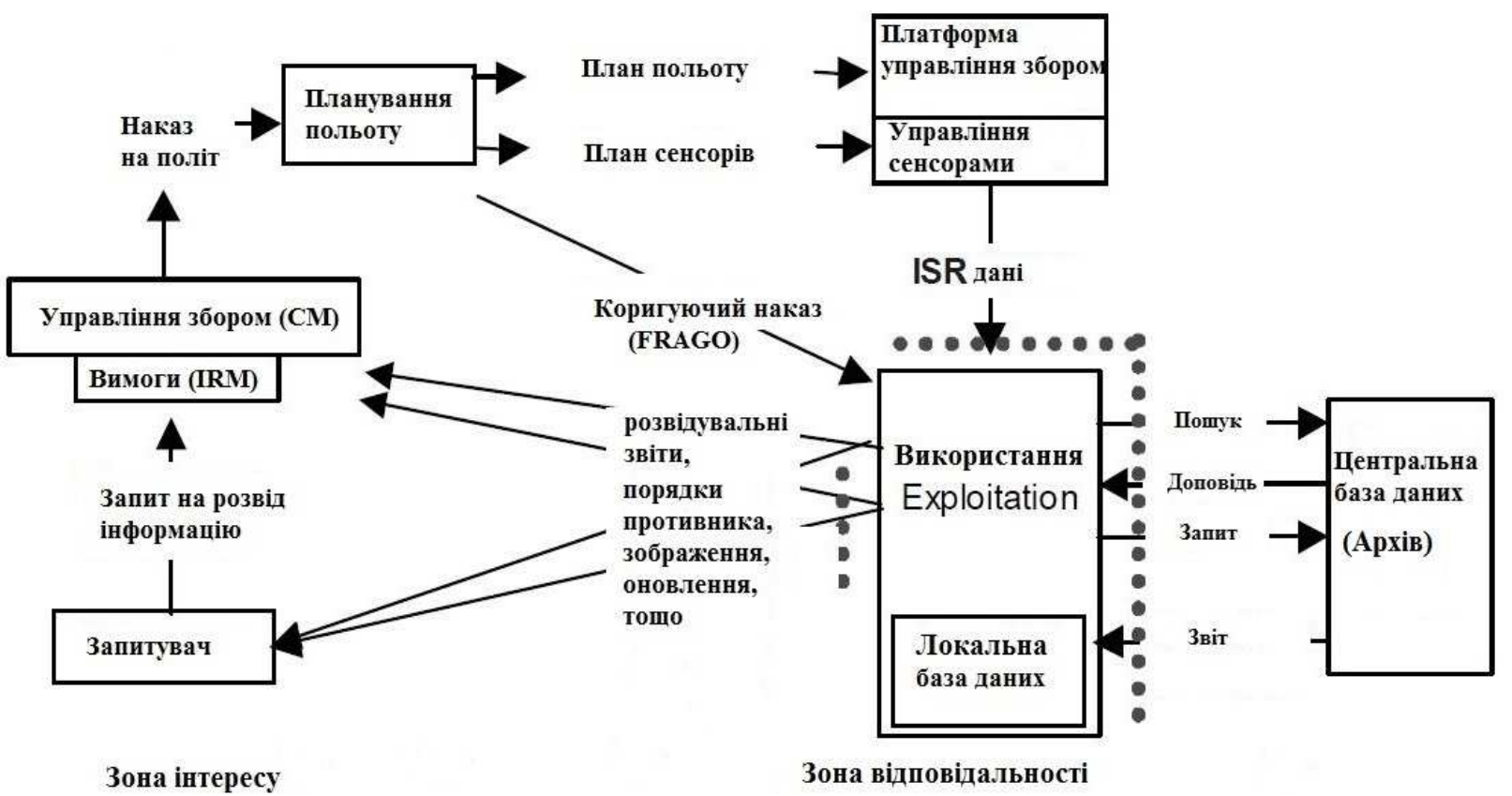

Рис. 9. Застосування БПЛА на кроці “використання” інформації

Як видно, дані, які могли бути втрачені через незначущість (рис. 5), отримали сенс завдяки застосованню процедур співставлення, оцінювання, аналізу, інтерпретації та цілеспрямованого залучення точніших інструментів розвідки. Рішення про ураження противника може бути прийняте як на основі обробленої інформації (рис. 6) негайно, так i на основі ситуаційної обізнаності (рис. 8), але після дорозвідки. До того ж досягнуті результати ураження будуть різними: від подавлення активності до повного знищення. В умовах існуючого конфлікту знищення цілі малоймовірне без точного визначення характеру цілі, ступеня фортифікації та координат до метрів.

Персонал, який виконує процедури кроку “використання”, має прагнути бути “попереду кризи”: використовуючи певні індикатори сенсорів і знання стандартних шаблонів противника, JISR-процес дозволяє передбачити наступні курси дій противника. Така “проактивна функція" розвідки дає змогу не тільки пришвидшити реакцію на дії противника, а, в ідеалі запобігти цим діям. Для цього кроки TCPED в on-line режимі мають проходити якомога швидше сприяючи прискоренню прийняття військового рішення i можливості негайного використання ситуаційної обізнаності, поширеної в оптимальному вигляді 3 розвідувального циклу в операційний.
Інтеграція розвідувального і операційного цииклів. JISR-процес не підміняє розвідувальний цикл, скоріше він $є$ частиною процесу інтеграції розвідки в операції. Через синхронізацію та інтеграцію розвідувальних i операційних процесів командири та їх штаби мають змогу визначати пріоритети, надавати вимоги та розподіляти наявні засоби в кожній конкретній операції. Місце JISR-процесу в синхронізації та інтеграції розвідувального й операційного циклів [5] наведено на рис. 10.

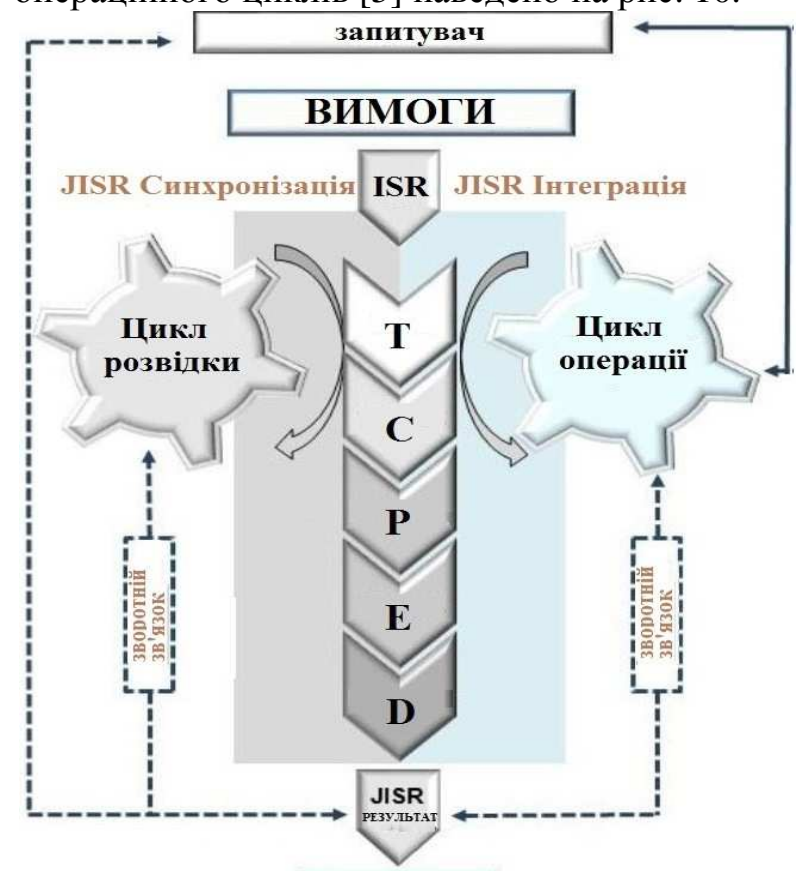

Рис. 10. Місце JISR процесу відносно розвідувального й операційного циклів 
Відповідальним за JISR синхронізацію має бути персонал секцій розвідки в той час, як відповідальним за інтеграцію результатів розвідки - персонал секцій операцій [4]. У будь-який момент дані або інформація з будьякого сенсора можуть i мають бути використані на кожному 3 рівнів командування для реакції на зміну бойового простору. Знання, поширене через тиждень, рівноцінне незнанню. Немає цінності в зібраних даних і ситуаційній обізнаності, якщо вони не були використані для виконання місії або оцінювання нанесеної шкоди противнику (BDA - battle damage assessment) [15].

Приклад схеми застосування JISRпроцесу в АТО (антитерористичній операції)
2017-2018 pр. наведено на рис. 11 і описано в попередній публікації [12]. Кроки JISR-процесу виконувались послідовно:

збір відбувався сенсорами на тактичному рівні;

обробка здійснювалась командирами груп різних видів розвідок, згуртованих у модулі (спостереження, цілевиявлення, тактична розвідка);

рішення щодо використання i поширення ситуаційної обізнаності виконував постійно діючий тактичний центр операцій (TOC - tactical operations center);

вимоги формулювались командуванням i були “штурвалом" усього процесу.

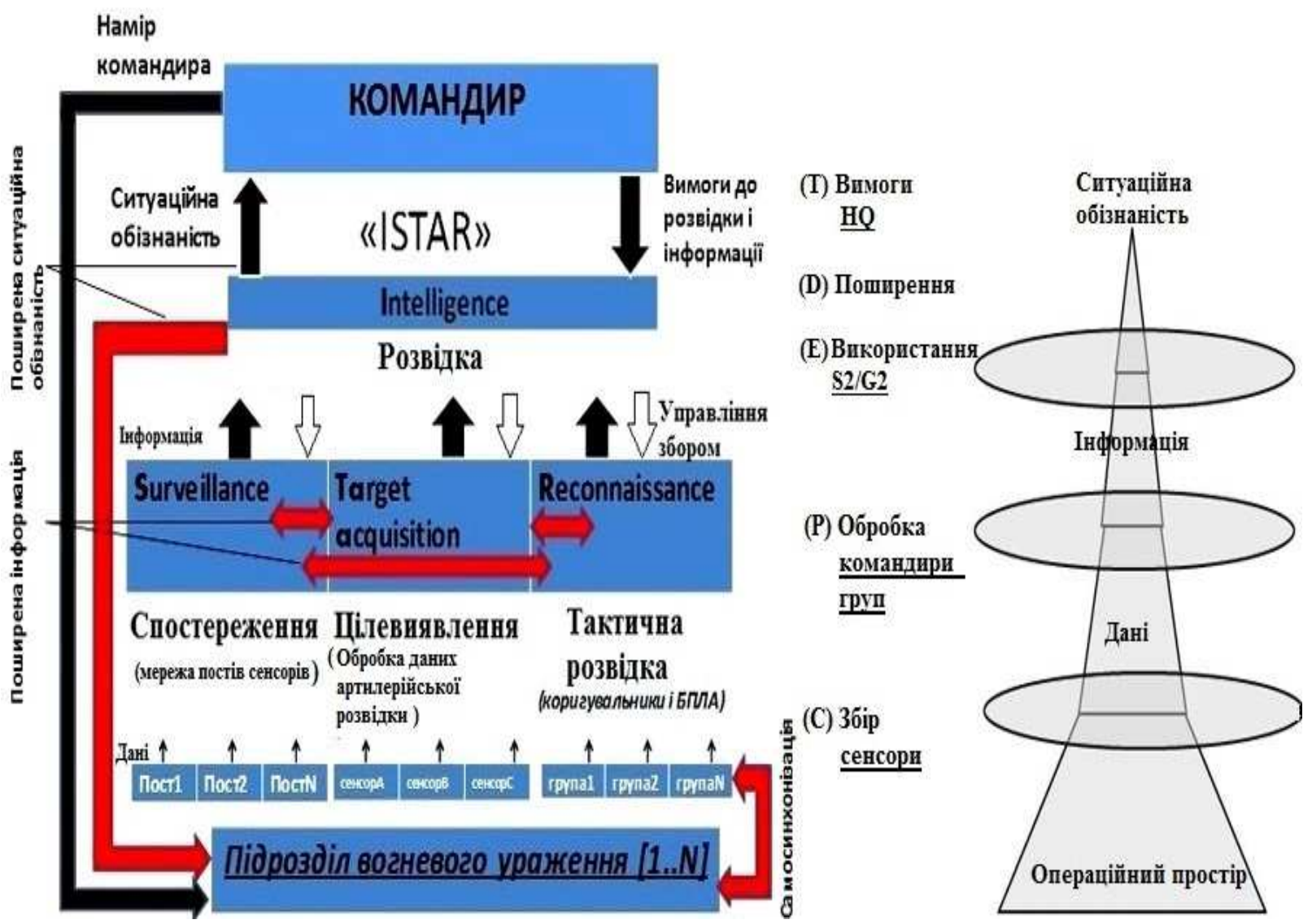

Pис. 11. Схема системи ISTAR, застосованої в АTO в 2017-2018 pp.

Важливим результатом інтеграції розвідки в операційний цикл було скорочення ланки "сенсор-система ураження" i мінімізація часу реакції сил місії на зміни в операційному просторі. Це стало можливим завдяки долученню тактичної ланки до результатів JISR процесу та делегуванню командирам тактичного рівня повноважень, заздалегідь визначених у "Правилах бойового застосування" ( ROE - rules of engagement). Правила бойового застосування містяться в оперативних наказах бойовим підрозділам i визначають обставини, умови, дії противника, за яких підрозділ починає необхідні визначені контрдії без очікування додаткових наказів вищих ланок командування. Чіткі рамки правил бойового застосування - запобіжник від переходу командуванням тактичного підрозділу визначених меж [16], з одного боку, i зрозумілий механізм прояву ініціативи та виконання місій командирами тактичної ланки - 3 іншого. Заздалегідь визначені правила бойового застосування можуть бути інструментом ефективного стримування противника в потенційно небезпечних ділянках як у зоні проведення ООС, так і поза іiі межами 
(наприклад, у смугах окупованих територій Придністров'я та Криму). JISR-процес за таких обставин виконується окремими тактичними підрозділами у зв'язці 3 приданими та суміжними підрозділами до моменту налагодження управління та комунікації з вищими ланками командування. Різні умови правил бойового застосування [8] тактичної ланки вогневого ураження наведено на рис. 12.

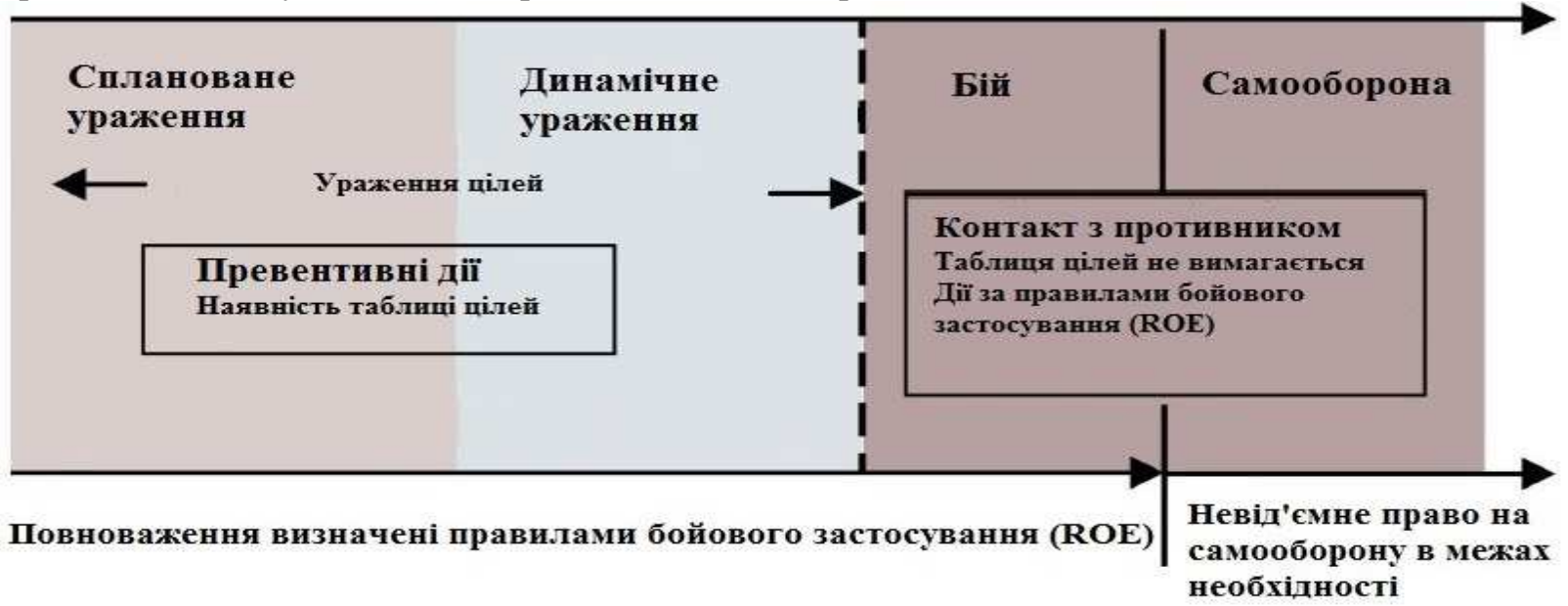

Рис. 12. Різні умови правил бойового застосування тактичної ланки вогневого ураження

Висновки. Здатність перетворити інформацію в звіт розвідки, на основі якого приймається військове рішення - вирішальна спроможність [17].

В умовах залучення великої кількості сенсорів задіяних в операції відбиття збройної агресії, та для ефективного їх застосування підрозділам операції необхідно дотримуватись єдиних розвідувальних процедур з управління вимогами до розвідки, збором даних, обробкою та поширенням інформації про зміни в операційному просторі.

Ключовим принципом розвідувальних процесів у доктринах НАТО є “централізоване планування - децентралізоване виконання", [5]. Цей принцип потребує імплементації як на оперативному, так i на тактичному рівнях процедур і технік об'єднаної розвідки, спостереження, тактичної розвідки (JISR) та цілевиявлення, що дасть змогу гармонізувати розвідувальні й операційні функції. До того ж персонал управління підрозділів тактичного рівня має отримати необхідні знання 3 ïx застосування на організованих постійно діючих навчальних курсах.

\section{СПИСОК ВИКОРИСТАНОЇ ЛІТЕРАТУРИ}

1. Veum K. Joint Intelligence, Surveillance \&Reconnaissance(JISR) in NATO - 2016. - 25p.

2. AJP-01 Allied Joint Doctrine - 2017. - 88p.

3. AJP-2 Allied Joint Doctrine for Intelligence, Counter-intelligence and Security - 2016. - 90p.

4. AJP-2.1 Allied Joint Doctrine for Intelligence Procedures - 2016. - 95p.

5. AJP-2.7 Allied Joint Doctrine for Joint Intelligence, Surveillance and Reconnaissance - 2016. - 56p.

6. AIntP-14 Joint Intelligence, Surveillance and
Reconnaissance (JISR) Procedures in Support of NATO Operations - 2016. - 76p.

7. AJP-3 Allied Joint Doctrine for the Conduct of Operations - 2011. - 122p.

8. AJP-3.9 Allied Joint Doctrine for Joint Targeting 2016. - 82p.

9. AJP-5 Allied Joint Doctrine for Operational-level Planning - 2013. - 299p.

10. ADP 2-0 Intelligence - 31 August 2012. - 28p.

11. Пащук Ю. Місце і роль ICTAР у системах розвідки провідних країн світу / Ю. М. Пащук, Ю. П. Сальник // Військово-технічний збірник. 2012. - №2(7). - С. 94-102.

12. Прозапас I. M. Досвід побудови системи ISTAR в ATO, особливості впровадження та перепони на шляху до підвищення бойової ефективності вогневих підрозділів // Збірник наукових праць Центру воєнно-стратегічних досліджень Національного університету оборони України імені Івана Черняховського. - 2017. - 3(61). С. 96-104. [Електронний ресурс]. - Режим доступу: http://journals.uran.ua/index.php/2304-2699/article/ viewFile/124144/118662

13. ATP 3-09.12 Field Artillery Target Acquisition 2015. - 144 p.

14. AEDP-2 NATO Intelligence, Surveillance, and Reconnaissance (ISR) Interoperability Architecture (NIIA), VOLUME 1: Architecture Description 2005. -33 p.

15. U.S. Army Field Manual (FM) 2-19.4: Brigade Combat Team Intelligence Operations. - 2008. $192 \mathrm{p}$.

16. U.S. Army Field Manual (FM) 2-0: Intelligence Operations. -2014 . - 105 p.

17. House of Commons. Session 2009-10. The contribution of ISTAR to operations. Publications on the internet. Defence Committee Publications. Defence - Eighth Report [Електронний ресурс]. Режим доступу: https://publications.parliament.uk/ $\mathrm{pa} / \mathrm{cm} 200910 / \mathrm{cmselect} / \mathrm{cmdfence} / 225 / 225$.pdf 


\section{Прозапас И. Н.}

В/ч 3057, Мариуполь

\section{Имплементация единых разведывательных процедур на оперативно- тактическом уровне - путь к преимуществу на поле боя \\ Резюме. В статье описаны принципы, содержащиеся в некоторых обновленных доктринах НАTO.} Показана возможность повышения эффективности управления разведкой (в условиях большого количества средств разведки, задействованных в операции) путем внедрения JISR-процесса для обоснования решения, что позволит не только своевременно реагировать, но и предотвращать действия противника.

Ключевые слова: цикл разведки; объединение; управление сбором; требования к разведке; взаимодействие; синхронизация; зона интереса; обнаружение целей; делегирование полномочий; правила боевого применения.

\section{Prozapas}

M/u 3057, Mariupol

Implementation of the joint intelligence procedures into the operational-tactical level - way to advantage in the battle space

Resume. The article describes principles of some updated NATO doctrines. Taking into account abundance of the intelligence assets involved into defying the aggression, an increase in the intelligence management efficiency may speed up MDMP due to JISR process which allows not only giving early reaction but even interference with enemy's course of action.

Keywords: intelligence cycle; joint; collection management; intelligence requirements; interoperability; synchronization; named area of interest; target acquisition; delegation of authority; rules of engagement. 